\title{
Understanding cell behavior in cultivation processes - A metabolic approach
}

\author{
Jonas Aretz ${ }^{1}$, Tobias Thüte ${ }^{1}$, Sebastian Scholz ${ }^{1}$, Klaudia Kersting ${ }^{1}$, Thomas Noll ${ }^{1,2}$, Heino Büntemeyer ${ }^{1 *}$ \\ From 23rd European Society for Animal Cell Technology (ESACT) Meeting: Better Cells for Better Health \\ Lille, France. 23-26 June 2013
}

\begin{abstract}
Background
During cultivation cells undergo a tremendous change in their metabolism when shifting from one state to another or when parameters are changed. To understand the changes in intracellular metabolite concentrations and their impact on cell performance we used a systematic approach. By employing the chemostat mode at different steady state conditions we investigated the alterations of the concentrations of key metabolites during cultivations of a human production cell line.
\end{abstract}

\section{Methods}

Chemostat cultivations were performed with the AGE1. hn AAT cell line (Probiogen AG, Berlin, Germany) and TC-42 medium (Teutocell AG, Bielefeld, Germany) in a fully controlled 2 litre benchtop bioreactor (Sartorius, Göttingen,Germany). Different dilution rates of $0.24 \mathrm{~d}^{-1}$, $0.33 \mathrm{~d}^{-1}$, and $0.40 \mathrm{~d}^{-1}$ and $\mathrm{pH}$ values of $\mathrm{pH} 6.9, \mathrm{pH} 7.15$, and $\mathrm{pH} 7.3$ were performed using the same bioreactor setup. For stopping the cell metabolism an established fast filtration method [1] was used for rapid quenching. Metabolites were extracted from cells using liquid/liquid extraction. Extracts were analyzed by using hydrophilic interaction chromatography (HILIC) and ESI-MS/MS mass spectometry. Extracellular amino acids and pyruvate were analyzed by pre-column derivatization and RP-HPLC [2], glucose and lactate using a YSI 2700 bioanalyser.

\section{Results}

The comparative analysis of the three steady state dilution rates shows the great impact of changing extracel- lular conditions on the intracellular metabolite pools which may also lead to an altered productivity. For example, as been shown in Figure 1A the specific pyruvate consumption rate, $\mathrm{qPyr}$, as well as the intracellular pyruvate pools decrease with increasing dilution rates, while qGlc and qGln increase at the same time. While some metabolite pools show great differences between different dilution rates others remain more or less constant. A malonate inhibition of the TCA cycle (Figure 1B) appears mainly at low dilution rates, which might be an effect of glucose and / or glutamine limitation at those steady states.

Although qGlc, qPyr as well as qGln decrease with increasing $\mathrm{pH}$ values (data not shown), the intracellular TCA pools remain constant due to a catabolism of further amino acids (Table 1). This may have led to a lower waste of ammonia, lactate and glycine at higher $\mathrm{pH}$ values.

The analysis of the intracellular nucleotide pools show that while the concentrations of almost all nucleotides dropped with increasing dilution rates, they were more or less stable at changing $\mathrm{pH}$ values (data not shown).

\section{Conclusions}

Although more data have to be raised to get a comprehensive insight into cell metabolism it could be shown that chemostat cultures performed at steady state conditions are a valuable tool for investigating cell behaviour on an intracellular basis. A much better data stability can be obtained than in batch or fed-batch cultures.

\footnotetext{
* Correspondence: heino.buentemeyer@uni-bielefeld.de

${ }^{1}$ Institute of Cell Culture Technology, Bielefeld University, Bielefeld, Germany Full list of author information is available at the end of the article
} 


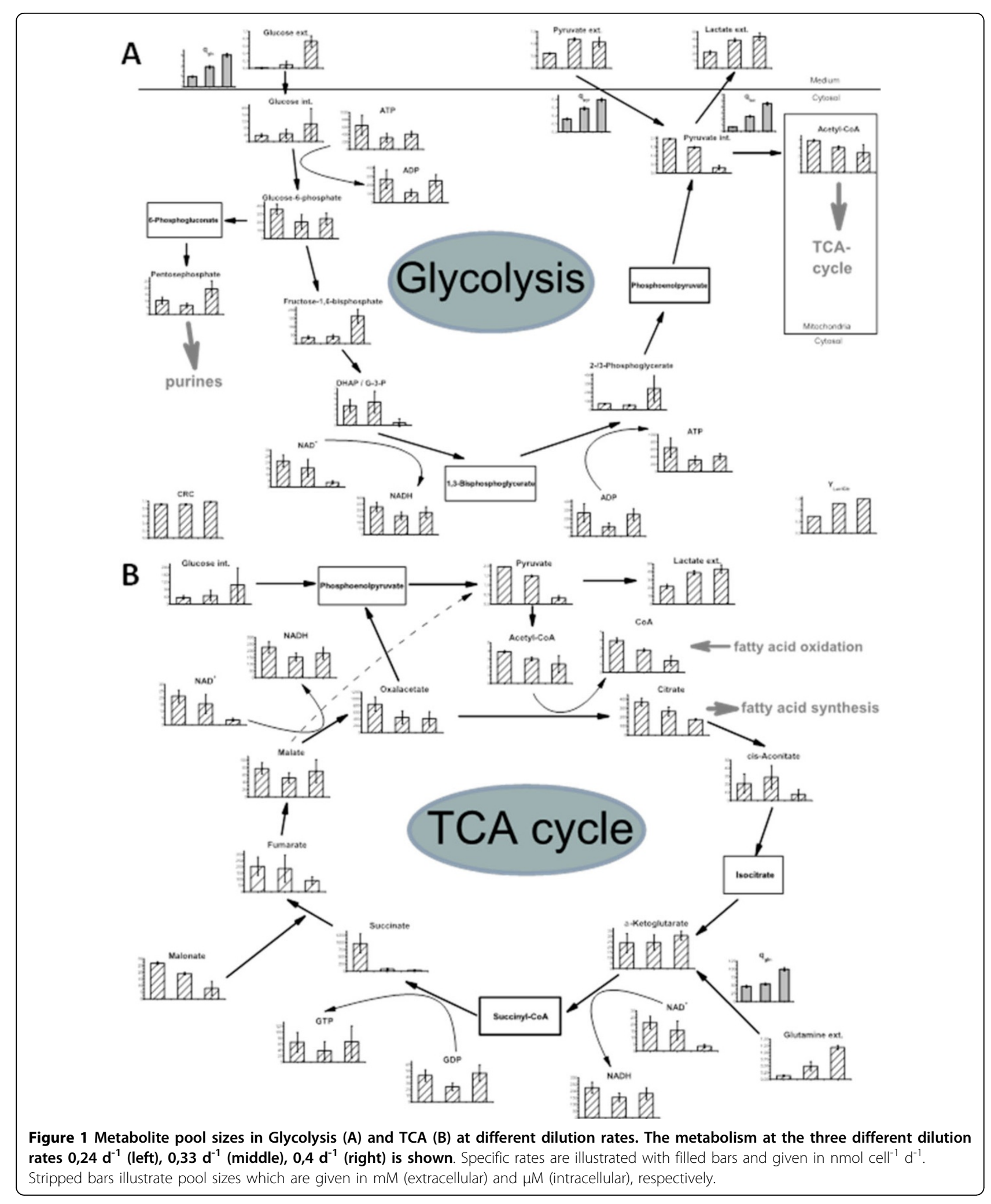


Table 1 Correlation of specific rates $\mathrm{q}_{\mathrm{xxx}}$ with the adjusted $\mathrm{pH}$ values during steady state

\begin{tabular}{lccc}
\hline & pH 6,9 & pH 7,15 & pH 7,3 \\
\hline$q_{\text {NH3 }}$ & $430 \pm 27$ & $243 \pm 9$ & $207 \pm 19$ \\
$q_{\text {Lac }}$ & $4751 \pm 298$ & $3766 \pm 143$ & $3548 \pm 325$ \\
$q_{\text {Glc }}$ & $-3660 \pm 230$ & $-3302 \pm 126$ & $-3301 \pm 302$ \\
$q_{\text {Pyr }}$ & $-155 \pm 10$ & $-121 \pm 5$ & $-84 \pm 8$ \\
$q_{\text {Gln }}$ & $-527 \pm 33$ & $-488 \pm 19$ & $-484 \pm 44$ \\
$q_{\text {Asp }}$ & $-63 \pm 4$ & $-123 \pm 5$ & $-153 \pm 14$ \\
$q_{\text {Glu }}$ & $66 \pm 4$ & $29 \pm 1$ & $-16 \pm 2$ \\
$q_{\text {Asn }}$ & $-17 \pm 1$ & $-42 \pm 2$ & $-45 \pm 4$ \\
$q_{\text {Ser }}$ & $-91 \pm 6$ & $-198 \pm 8$ & $-191 \pm 17$ \\
$q_{\text {His }}$ & $-13 \pm 1$ & $-23 \pm 1$ & $-5 \pm 1$ \\
$q_{\text {Gly }}$ & $32 \pm 2$ & $9 \pm 0$ & $7 \pm 1$ \\
$q_{\text {Thr }}$ & $-26 \pm 2$ & $61 \pm 2$ & $67 \pm 6$ \\
$q_{\text {Arg }}$ & $-39 \pm 2$ & $-97 \pm 4$ & $-109 \pm 10$ \\
$q_{\text {Ala }}$ & $101 \pm 6$ & $48 \pm 2$ & $99 \pm 9$ \\
$q_{\text {Tyr }}$ & $-10 \pm 1$ & $-29 \pm 1$ & $29 \pm 2$ \\
$q_{\text {Met }}$ & $-20 \pm 1$ & $-39 \pm 2$ & $-40 \pm 4$ \\
$q_{\text {Val }}$ & $-37 \pm 2$ & $-79 \pm 3$ & $-88 \pm 8$ \\
$q_{\text {Trp }}$ & $-5 \pm 0$ & $-8 \pm 0$ & $-9 \pm 1$ \\
$q_{\text {Phe }}$ & $-10 \pm 1$ & $-36 \pm 1$ & $-36 \pm 3$ \\
$q_{\text {Ille }}$ & $-35 \pm 2$ & $-68 \pm 3$ & $-72 \pm 7$ \\
$q_{\text {Leu }}$ & $-63 \pm 4$ & $-111 \pm 4$ & $-122 \pm 11$ \\
$q_{\text {Lys }}$ & $-21 \pm 1$ & $-89 \pm 3$ & $-100 \pm 9$ \\
\hline
\end{tabular}

The specific rates are given in pmol cell-1 $\mathrm{d}^{-1}$. (Negative values indicate consumed metabolites.)

\section{Acknowledgements}

Funding by the BMBF, Germany, Grand Nr. 0315275A is gratefully acknowledged.

\section{Authors' details}

'Institute of Cell Culture Technology, Bielefeld University, Bielefeld, Germany.

${ }^{2}$ Center for Biotechnology (CeBiTec), Bielefeld University, Bielefeld, Germany.

\section{Published: 4 December 2013}

\section{References}

1. Volmer M, Northoff S, Scholz S, Thüte T, Büntemeyer H, Noll T: Fast filtration for metabolome sampling of suspended animal cells. App/ Microbiol Biotechnol 2011, 94:659-671.

2. Büntemeyer H: Methods for off-line analysis in animal cell culture. In Encyclopedia of Industrial Biotechnology. Bioprocess, Bioseparation, and Cell Technology. New York: Wiley;Flickinger M 2010:

doi:10.1186/1753-6561-7-S6-P90

Cite this article as: Aretz et al:: Understanding cell behavior in cultivation processes - A metabolic approach. BMC Proceedings 2013 7(Suppl 6):P90.

Submit your next manuscript to BioMed Central and take full advantage of:

- Convenient online submission

- Thorough peer review

- No space constraints or color figure charges

- Immediate publication on acceptance

- Inclusion in PubMed, CAS, Scopus and Google Scholar

- Research which is freely available for redistribution

Submit your manuscript at www.biomedcentral.com/submit
C Biomed Central 